François B. Lanoë (1), Joshua D. Reuther (2, 3), Charles E. Holmes (2)

\title{
Task-Specific Sites and Paleoindian Landscape Use in the Shaw Creek Flats, Alaska
}

(1) School of Anthropology, University of Arizona

(2) Department of Anthropology, University of Alaska Fairbanks

(3) University of Alaska Fairbanks Museum of the North

Corresponding author: lanoe@email.arizona.edu, (+1) 6515005696

\section{Acknowledgments}

This project received support from the National Science Foundation grant BCS-1504654, the Lewis and Clark Fellowship of the American Philosophical Society, the Otto Geist Fund of the University of Alaska Museum of the North, and the Social and Behavioral Sciences Research Institute and the School of Anthropology at the University of Arizona.

This article greatly benefited from discussions with Mary Stiner, Steven Kuhn, Vance Holliday, and John Olsen (University of Arizona), Ben Potter (University of Alaska Fairbanks), Richard VanderHoek (Alaska Office of History and Archaeology), David Yesner (University of Alaska Anchorage), and from comments from three anonymous reviewers. Help with conducting this research was provided by Meredith Wismer (University of Iowa), Amy Clark, Benjamin Bellorado, Ismael Sánchez Morales, and Jennifer Kielhofer (University of Arizona), Matthew Pailes (University of Oklahoma), and Robert Bowman and David Plaskett (University of Alaska Fairbanks). 


\begin{abstract}
The Shaw Creek Flats and nearby middle Tanana river, in central Alaska, constitute one of the areas in the Americas with the densest known distribution of Late Glacial (about 14,500-11,700 cal. B.P.) archaeological sites. Local high rates of sediment deposition and low post-depositional disturbance allow for the interpretation of the function of archaeological occupations within larger economic and mobility strategies. Residential sites used over the long term seem to be located near critical but immovable resources such as clear water and vegetation. The spatial association of artifacts and faunal remains at other sites in the Flats suggest that they were specialized, short-lived locations dedicated to a single or few activities. For instance, the site of Swan Point Cultural Zone 4b is interpreted as a workshop related to the production of composite tools, particularly on mammoth ivory; and the site of Keystone Dune is interpreted as a camp related to wapiti (Cervus elaphus) hunting. These task-specific sites and others were probably used as part of a predominantly logistical mobility and economy strategy, which maximized efficiency in harvesting and processing resources that were distributed heterogeneously on the landscape.
\end{abstract}

\title{
Keywords
}

Mobility; landscape; Paleoindian; Beringia 


\section{Introduction}

How groups of hunter-gatherers behave within an economically-defined landscape is a central focus of archaeological research. Economic organization is tightly intertwined with diet, technology, other aspects of material culture, and bears heavily on the larger ecological role of people within ecosystems. Many major prehistoric socio-economic transitions were characterized by changes in how people moved around and exploited the resources in their territories. During the Late Pleistocene, characterizing hunter-gatherer economic organization is central to understanding issues related to their dispersal into un-colonized landscapes, throughout subarctic Eurasia and the Americas, as well as their possible ecological role in the turnover of large mammalian fauna.

Ethnographically documented hunter-gatherers exhibit a wide spectrum of economic and mobility strategies (Kelly 2013). How people acquire resources typically depends on the scale at which these resources are distributed across the landscape. In environments where the resources targeted by hunter-gatherers are distributed homogeneously in space and time, people tend to favor a strategy incorporating frequent residential mobility (Binford 1980, 1982; Grove 2009; Kelly 1983). They exploit resources in the immediate vicinity, generally a daily foraging radius, of a residential camp. The camp is moved to another location when resources in the patch are diminished to the point that other patches become more attractive (Bird and O'Connell 2006; Venkataraman et al. 2017). Typically, the frequency of residential moves correlates negatively with the resource density in the environment (Kelly 2013).

In environments where targeted resources are distributed heterogeneously over the landscape, no patch contains all of the resources needed by a group of hunter-gatherers, and there are often gaps between concentrations of key resources. People then rely more on logistical mobility strategies (Binford 1980, 1982; Grove 2010; Kelly 2013). The location of residential camps depends on the search and transport costs associated with some key resources, and some group members conduct specialized trips to supply the residential camp with resources that are located farther away. Resources acquired during these trips can then be stored at the residential camp for use by some or all members of the group. The location and duration of occupation of a residential camp in the case of a logistical strategy depends on a complex interplay between the costs associated with the acquisition, transport, and processing of each resource. As a rule, groups that emphasize logistical mobility move their residential camps less often and use them for longer periods of time.

Characterizing resource distribution on a landscape depends on the scale of consideration. Kelly and Todd (1988) famously proposed that Late Pleistocene hunter-gatherers dispersing for the first time into the Americas used a highly mobile residential strategy based on the exploitation of megafauna. Having little knowledge of the distribution of resources, or "resource geography," (Kelly 2003) of the landscapes they colonized, people would have targeted high-visibility and high-return large-bodied mammals. These resources are assumed to have been "regionally 
abundant, but locally unpredictable” (Kelly and Todd 1988, p. 235); in other words, megafauna would have been homogeneously distributed at a regional scale but heterogeneously at a local scale. In conditions of low population density and low inter-group competition, Late Pleistocene people would have moved over larger distances, creating sites with redundant assemblages, and possibly depleting megafauna populations as they went. In this scenario, hunter-gatherers would have dramatically disturbed otherwise well-established large mammal communities and contributed to the extinction of Rancholabrean fauna (Kelly and Todd 1988).

This model of Late Pleistocene mobility and economy is attractive considering some aspects of the archaeological record in the mid-latitudes of North America, particularly the evidence for proboscidean hunting (Surovell and Waguespack 2008) long-distance raw material procurement, and homogeneity of a material culture dominated by long-use life bifacial tools (Kelly and Todd 1988). However, other researchers have disputed some of the claims of this model, particularly regarding lithic technology (e.g. Bamforth 2003), and argued that the archaeological record also offers evidence for extensive use of diverse resources and that mobility and economic systems may have varied by region (e.g. Chatters et al. 2012; Jones and Beck 2012).

The Late Pleistocene archaeological record in many regions of North America generally lacks the resolution to test our models of hunter-gatherer economy and mobility, because of taphonomy issues that are inherent to the geological contexts in which traces of human occupation are typically preserved. In contrast, the record from the Shaw Creek Flats, in subarctic eastern Beringia, offers a unique potential for research because of the number of documented occupations and their generally good preservation context. Here we present results from a multiscale spatial analysis, ranging from individual site to the collective landscape, to discuss evidence for the economic organization of Late Glacial hunter-gatherers in the Shaw Creek Flats and its implications for human dispersal in the subarctic and the Americas at the end of the Pleistocene.

\section{Identifying the Function of Hunter-Gatherer Sites}

In this paper we discuss hunter-gatherer economic and mobility strategies in the Late Glacial of the Shaw Creek Flats based on interpretations over the function of archaeological occupations. We differentiate sites depending on their economic role in a larger landscape, using as criteria the duration of occupation and nature of activities conducted therein. To that effect we differentiate residential and task-specific sites adapting Lewis Binford's (1980, 1982) seminal model of hunter-gatherer settlement systems.

Residential sites are defined as being used over longer periods of time by one to several households that include adult men and women, children, and the elderly. Residential sites, or base camps, function as central places to which resources are brought to be consumed or processed by the group, and where most technological and subsistence activities are performed 
(Binford 1980, 1982). The location of resources in the landscape conditions the suitable areas for establishing residential camps. Hunter-gatherers are interested in a diversity of resources; these include food, water, fuel, and raw material, the first three of which are consumed on a daily basis. Water and fuel are comparatively costly to transport (Kelly 2013) and are likely to have been of first importance for choosing the location of a residential camp (Table 1).

\begin{tabular}{|c|c|c|}
\hline Criteria & Residential Site & Task-Specific Site \\
\hline Location & $\begin{array}{l}\text { near water bodies, } \\
\text { woody vegetation }\end{array}$ & $\begin{array}{c}\text { near specific resource } \\
\text { patches }\end{array}$ \\
\hline Accessibility & near rivers & variable \\
\hline Orientation & south & variable \\
\hline Occupation size & larger & smaller \\
\hline Material density & higher and consistent & $\begin{array}{c}\text { lower; } \\
\text { or high but clustered }\end{array}$ \\
\hline Material diversity & high & low \\
\hline Activity areas & indistinct & well-defined \\
\hline Constructed structures & more elaborate & absent or less elaborate \\
\hline
\end{tabular}

Table 1. Summary of archaeological criteria used to differentiate residential and task-specific sites; discussion and references in-text.

The longer duration of occupation and higher complexity of activities undertaken at a residential site should be reflected in both the location of the site within a particular landform and by the composition and spatial distribution of its archaeological assemblage (Table 1). For instance, in the subarctic, people are likely to have favored southern exposures and invested in more elaborate habitation structures at longer-term residential occupations, for reasons of comfort (e.g. Binford 1978, 1990; Surovell and O’Brien 2016). Likewise, by-products from consumption and technological activities are likely to become mixed over the time of occupation of the site due to re-using the same locations for different activities, or through periodic cleaning and disposal (Binford 1983; Waguespack and Surovell 2014).

Residential sites centralize the acquisition and processing of resources, regardless of whether hunter-gatherers employ mobility strategies that are dominantly residential or dominantly logistical; differences between residential sites that are part of a dominantly residential versus logistical mobility strategy essentially boils down to how far away resources were acquired (Binford 1980, 1982). Procedures implemented to reduce transport costs can inform how the residential site functioned in a larger economic and mobility system (Kelly 2013). Where resources are dispersed and acquired through logistical trips, transport costs are most important and can be reduced by conducting primary processing of resources (e.g. large game, toolstone) at the place of extraction (e.g. Beck et al. 2002). Other strategies to reduce transport costs include prolonging the use-lives of the artifacts that are made on costly raw material (Kuhn 1995), and 
establishing residential camps near routes of travel. In subarctic lowlands, rivers provide natural low-slope routes for movement (e.g. McKennan 1981), and establishing residential camps near rivers would also have made the relocation of a residential camp and communication with other groups easier.

In contrast to residential sites, task-specific sites are the result of acquiring and/or processing a specific resource by a subset of specialists within the group and may be used for a relatively short period of time (Binford 1980). Despite their short duration of occupation, some taskspecific sites will accumulate a large quantity of archaeological material because the activity generates a lot of waste (e.g. quarry, kill-site) or because a location is re-used repeatedly for the same purpose over a long period of time (Surovell 2009). In contrast to residential sites, though, the low level of behavioral complexity at such sites should be reflected in the composition and spatial distribution of their archaeological assemblage (Table 1).

In practice, most sites represent palimpsests of several occupations in which quantity and duration are difficult to estimate. Good locations may be used again and again for the same or different purposes, and a high diversity and density of archaeological materials at a site can result from a single, long-term residential occupation, or from many short-term logistical occupations (Clark 2016; Surovell 2009). Task-specific sites typically exist at lower densities than residential sites, and may go unrecognized in many geological contexts in Beringia (Rasic 2011) or are blurred within palimpsests representing several distinct occupations (Hoffecker 2011; Surovell 2009).

\section{The Shaw Creek Flats}

The Shaw Creek Flats in central Alaska is an alluvial plain or terrace created by the aggradation of the Tanana River during the Last Glacial Maximum (Reger et al. 2008). The Flats and the surrounding Yukon-Tanana Uplands are drained by Shaw Creek and its tributaries, which eventually feed the Tanana River (Figure 1). The modern landscape is dominated by wetlands, muskeg, and black spruce (Picea mariana) forests in the lowlands, and by closed canopy forests of white spruce (Picea alba) and aspen (Populus tremuloides) on the hills (Chapin III et al. 2006).

During the Late Glacial (14,500-11,700 cal B.P.), when precipitation was 35-75\% lower than present (Barber and Finney 2000), the Flats were drier and more unstable than today. Extent lakes were absent or at low levels until about 11,000 cal B.P. (Bigelow 1997; Wooller et al. 2012). High-energy aeolian deposition prevented extensive soil succession (Dilley 1998; Reuther et al. 2016). Vegetation was dominated by shrub birch (Betula nana) and graminoids (Poaceae and Cyperaceae) until about 12,000 cal B.P. (Bigelow and Powers 2001). Poplars (Populus spp.) appeared around 13,000 cal B.P. and began to dominate the record by 12,000 cal B.P. (Graf and 
Bigelow 2011; Reuther et al. 2016), followed by white spruce by 10,000 cal B.P. (Anderson et al. 2004).

Large herbivore guilds were dominated by woolly mammoth (Mammuthus primigenius), Yukon horse (Equus lambei) and steppe bison (Bison priscus) until about 15,000-14,000 cal B.P. (Guthrie 1990, 2006). Wapiti (Cervus elaphus) and moose (Alces alces), along with bison (Bison cf. priscus) become dominant in the record after the extinction of mammoth and horse (Guthrie 2006; Lanoë et al. 2017). Migratory waterfowl (Anatidae) are first recorded by 14,000 cal B.P. (Lanoë and Holmes 2016; Yesner 2001) and anadromous fish (Salmonidae) by 11,800 cal B.P. (Choy et al. 2016; Halffman et al. 2015), following changes in the location and extant of major regional biogeographic barriers in the Late Glacial.

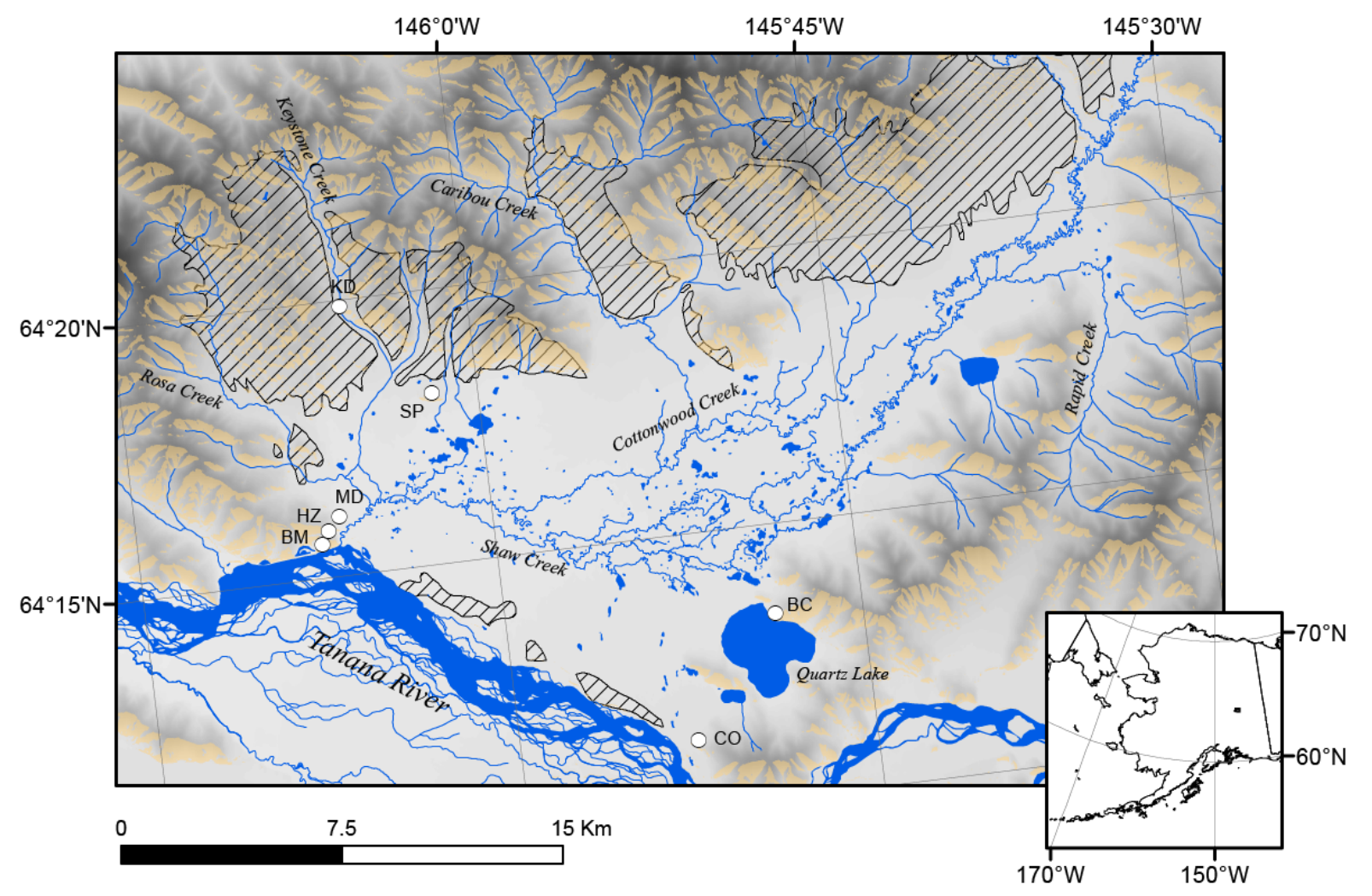

Figure 1. Topographic and geologic variation in the Shaw Creek Flats with sites mentioned in the text: Swan Point (SP), Bachner (BC), Broken Mammoth (BM), Cook (CO), Keystone Dune (KD), Mead (MD), Holzman (HZ). Areas in yellow have higher slope $\left(>10^{\circ}\right)$ and are oriented to the south $\left(135-225^{\circ}\right)$ reflecting higher drainage and insolation. Hatched areas represent sand sheets deposited during the Late Glacial (data from Weber et al. 1978). A least-cost path linking sites deep in the Flats to sites by the Tanana River would follow Keystone Creek down to Shaw Creek, then Shaw Creek down to the Tanana River. 
The Shaw Creek Flats include one of the densest known concentrations of buried, in situ Pleistocene archaeological sites in the Americas with 12 to 16 documented occupations in an area roughly $20 \mathrm{~km}$ by $8 \mathrm{~km}$ (Table 2, Figure 1). Diagnostic archaeological material recovered at Late Glacial sites in the Flats are dominated by bifacial points and microblades produced by the Campus method and these assemblages have been assigned to the Chindadn culture of eastern Beringia (Holmes 2011). One exception is the occupation of Swan Point Cultural Zone 4b (hereafter CZ4b) (Holmes et al. 1996). Arguably the oldest documented site in northern North America, it is dominated by burins and microblades produced by the Yubetsu method (Gómez Coutouly 2012) and has been assigned to the Dyuktai culture recorded in the whole of Beringia (Holmes 2011).

\begin{tabular}{|l|c|l|}
\hline Occupation & Date (cal B.P.) & References \\
\hline Mead CZ3b & $12,120-11,850$ & Potter et al. 2013 \\
\hline Broken Mammoth CZ3 & $12,386-11,769$ & Yesner 2001 \\
\hline Swan Point CZ3 (a?, b) & $12,830-11,390$ & Holmes 2014 \\
\hline Cook, Lower Component & $12,527-12,046$ & this paper \\
\hline Holzman (a/b?) & $13,250-11,620$ & Wygal et al. 2016 \\
\hline Bachner, Component 1 & $13,100-12,700$ & Wooller et al. 2012 \\
\hline Mead CZ4 & $13,110-12,790$ & Potter et al. 2013 \\
\hline Swan Point CZ4a & $13,420-13,080$ & Holmes 2014 \\
\hline Keystone Dune & $13,400-13,220$ & Reuther et al. 2016 \\
\hline Mead CZ5 & $13,440-13,200$ & Potter et al. 2013 \\
\hline Broken Mammoth CZ4 (a/b/c?) & $13,647-13,152$ & Yesner 2001 \\
\hline Swan Point CZ4b & $14,150-13,870$ & Lanoë and Holmes 2016 \\
\hline
\end{tabular}

Table 2. Known Late Glacial occupations in the Shaw Creek Flats. Previously unpublished date from the Cook site (AA-106445): 10,400 $\pm 60{ }^{14} \mathrm{C}$ B.P., on bone collagen, $\delta^{13} \mathrm{C}=-20.0 \%$; calibrated here with OxCal 4.2 and IntCal 13 (Bronk Ramsey 1994, 2009; Reimer et al. 2013).

Landforms in the Flats are dominated by aeolian sediments deposited by persistent winds with abundant sediment supply during the Late Glacial (Dilley 1998; Reuther et al. 2016). These sediments are carbonaceaous and slightly alkaline favoring the preservation of biogenic materials in Late Glacial archaeological occupations. These are generally associated with thin buried dark brown sandy and silty loam soil (Ab) horizons that provide stratigraphic landmarks allowing archaeologists to identify past surfaces and the extent of cryo-, bio- or tectonoturbation. Sediment deposition rates are high during the Late Glacial compared to later periods. They range from about $1 \mathrm{~cm}$ per century at Mead and Swan Point sites, up to 5 to $7 \mathrm{~cm}$ per century at the Bachner, Tannenbaum, and Keystone localities, and generally buried stable surfaces and helped protect human occupations from post-depositional disturbance (Table 3). In several sites, or portions of sites, archaeologically-sterile horizons separate non-contemporaneous occupations. In 
this case, high chronological resolution and preserved spatial organization allow for an accurate interpretation of the function of the occupations. Other occupations, such as Broken Mammoth CZ4 a/b/c or Swan Point CZ3 a/b, are more difficult to interpret because of a lower stratigraphic resolution and the formation of palimpsests (Table 2). Sites such as Bachner and Cook require more extensive excavations to provide reliable interpretations of human behavior. Functional interpretations in this paper focus on the best preserved and documented Late Glacial occupations of the Flats.

\begin{tabular}{|l|c|c|c|c|c|c|}
\hline Site & $\begin{array}{c}\text { Section Depth } \\
\text { (cm below } \\
\text { surface) }\end{array}$ & $\begin{array}{c}\text { Date Range } \\
\text { (cal B.P.) }\end{array}$ & Sediment & $\mathbf{p H}$ & Paleosols & $\begin{array}{c}\text { Deposition Rate } \\
\text { (cm/century) }\end{array}$ \\
\hline Bachner Site & $139-115$ & $12,370-11,860$ & Loess & $7.8-8.1$ & 5 & 4.7 \\
\hline Camp Section & $158-127$ & $12,584-11,618$ & Loess & $8.3-8.6$ & 3 to 5 & 3.2 \\
\hline $\begin{array}{l}\text { Tannenbaum } \\
\text { Section }\end{array}$ & $168-122$ & $12,698-11,803$ & Loess & - & 4 & 5.1 \\
\hline 288 Bluff Section & $142-102$ & $12,864-12,045$ & Loess & $8.1-8.6$ & 5 to 11 & 4.9 \\
\hline $\begin{array}{l}\text { Broken Mammoth } \\
\text { Site }\end{array}$ & $150-127$ & $13,295-12,090$ & Loess & $8.3-8.5$ & 4 to 6 & 1.9 \\
\hline Cook Site & $195-90$ & $12,287-9,349$ & Loess & $6.8-8.8$ & 6 to 8 & 3.6 \\
\hline Keystone Dune & $470-315$ & $13,300-11,160$ & Sand & - & $>18$ & 7.2 \\
\hline Mead Site & $137-125$ & $13,320-11,985$ & Loess & $8.5-8.6$ & 4 to 6 & 0.9 \\
\hline Swan Point Site & $78-54$ & $14,010-11,680$ & Loess & $6.8-7.7$ & 1 to 3 & 1.0 \\
\hline
\end{tabular}

Table 3. Rates of sediment deposition during the Late Glacial at archaeological and geological localities of the Shaw Creek Flats (data retrieved from Dilley 1998, Potter et al. 2013, Reuther 2013, Reuther et al. 2016; rates calculated following Stein et al. [2003]). The ends of the date ranges are averages of intervals calibrated with OxCal 4.2 and IntCal 13 (Bronk Ramsey 1994, 2009; Reimer et al. 2013). For the Cook site, the date at $195 \mathrm{~cm}$ BS is referenced in Table 2; the date at $90 \mathrm{~cm}$ BS is as follows (UGAMS--18145): 8,320 $\pm 30{ }^{14} \mathrm{C}$ B.P., on bone collagen, $\delta^{13} \mathrm{C}=$ $-20.6 \%$ o, $\delta^{15} \mathrm{~N}=2.4 \%$.

\section{Residential Sites}

Broken Mammoth CZ3 and Mead CZ4 are well-documented occupations located $1.2 \mathrm{~km}$ apart on a bluff overlooking the confluence of Shaw Creek and the Tanana River. They meet the expectations for residential sites outlined in Table 1, confirming the interpretations made by the original excavators (Potter et al. 2013).

The Broken Mammoth and Mead sites are oriented to the south along the bluff edge as would be expected for sites used over long durations. The sites are also located in the immediate vicinity of the Tanana River (Table 4). The recovery of obsidian at Swan Point (CZ3) and Broken Mammoth (CZ4) from Batza Téna and Wiki Peak $420 \mathrm{~km}$ NW and $360 \mathrm{~km}$ SE distance from the sites, respectively (Reuther et al. 2011), indicates that Late Glacial people of the Shaw Creek 
Flats moved or communicated over long distances. The Tanana River probably channeled longdistance mobility and/or communication in the past much as it does today; in addition, proximity to the Tanana River probably facilitated residential camp relocation throughout its drainage.

\begin{tabular}{|c|c|c|c|c|c|c|c|c|c|}
\hline Occupation & $\begin{array}{l}\text { Elevation } \\
\text { amsl (m) }\end{array}$ & Aspect & $\begin{array}{c}\begin{array}{c}\text { Distance } \\
\text { to }\end{array} \\
\text { Tanana } \\
\text { River } \\
\text { (km) } \\
\end{array}$ & $\begin{array}{c}\text { Distance } \\
\text { to Shaw } \\
\text { Creek } \\
\text { (km) }\end{array}$ & $\begin{array}{c}\text { Nearest } \\
\text { Creek } \\
(\mathbf{k m})\end{array}$ & $\begin{array}{l}\text { Excavated } \\
\text { Area }\left(\mathrm{m}^{2}\right)\end{array}$ & $\begin{array}{c}\text { Hearth } \\
\text { Density } \\
\left(/ \mathbf{m}^{2}\right)\end{array}$ & $\begin{array}{c}\text { Fauna } \\
\text { Density } \\
\left(/ \mathbf{m}^{2}\right)\end{array}$ & $\begin{array}{c}\text { Lithics } \\
\text { Density } \\
\left(/ \mathbf{m}^{2}\right)\end{array}$ \\
\hline $\begin{array}{l}\text { Broken } \\
\text { Mammoth } \\
\text { CZ3 }\end{array}$ & 295 & SSE & $<0.1$ & 0.4 & 0.4 & 408 & .015 & 13.1 & 9.8 \\
\hline Mead CZ4 & 290 & SE & 1.0 & 0.5 & 0.5 & 128 & .023 & $\sim 1.6$ & 11.7 \\
\hline $\begin{array}{l}\text { Swan Point } \\
\text { CZ4b }\end{array}$ & 320 & $360^{\circ}$ & 6.0 & 3.3 & 1.6 & 80 & .025 & 18.9 & 63.9 \\
\hline $\begin{array}{l}\text { Keystone } \\
\text { Dune }\end{array}$ & 350 & SSW & 7.4 & 5.6 & 0.5 & 22 & .091 & 5.7 & 8.0 \\
\hline
\end{tabular}

Table 4. Characteristics of several Late Glacial occupations in the Shaw Creek Flats. Densities were calculated from Krasinski and Yesner (2008) for Broken Mammoth; from original data for Swan Point and Keystone Dune; and estimated from figures and text in Potter et al. (2013) for Mead.

The Broken Mammoth and Mead sites are located in the immediate vicinity of Shaw Creek (Table 4). Shaw Creek and its tributaries provided the least costly path to the Flats from the Tanana River and would have facilitated mobility in that area (Figure 1). Shaw Creek is much clearer than the turbid, sediment-loaded Tanana River: today colors from Landsat photographs near the confluence range between RGB values 0.68-0.74 for the Tanana River and 0.19-0.25 for Shaw Creek. Shaw Creek was probably favored for drinking water as these two water courses may have been some of the only perennial water sources during the drier Late Glacial. Wood fuel was probably present along the Tanana River and Shaw Creek during most of the Late Glacial in the form of gallery forests of Populus spp. and Salix spp. (Anderson and Brubaker 1994; Bigelow 1997). In contrast, at Swan Point CZ4b further from the Tanana River, people did not have easy access to wood, and instead used readily available bones as fuel (Holmes 2011; Kedrowski et al. 2009) even though the thermic properties of animal tissues are not as good as those of woody vegetation (Théry-Parisot and Costamagno 2005). Lastly, local lithic raw materials were available in the bed of the Tanana River and on the bluff in the form of secondary chert cobbles and quartz nodules. These were used heavily at both Mead CZ4 and Broken Mammoth CZ3 (Potter et al. 2013).

Densities of archaeological materials in the Broken Mammoth CZ3 and Mead CZ4 occupations are comparable or even lower than other occupations in the Flats (Table 4), but materials were recorded at consistent densities over very large surface areas (Krasinski and Yesner 2008; Potter et al. 2013). In contrast, materials at Swan Point CZ4b and Keystone Dune were recorded in restricted areas with high densities of archaeological materials (Lanoë and Holmes 2016). The Keystone Dune occupation, though partly eroded along the dune edge, does not seem to have 
extended over more than $\sim 15 \mathrm{~m}^{2}$ (see below). In addition, Swan Point CZ4b is atypical as a short-term occupation and high densities of archaeological materials should not be interpreted as reflective of a residential occupation. Evidence from the analysis of faunal and lithic materials and their spatial layout instead suggest that people at this location focused on a single activity, producing microblade-based composite tools, but that they created disproportionately large amounts of waste from this activity (Lanoë and Holmes 2016).

Archaeological materials recovered at Broken Mammoth CZ3 and Mead CZ4 are diverse (Table 5). Tool forms in particular suggest a diversity of activities, such as hide tanning, tool and textile making, in addition to primary reduction of local chert cobbles and quartz nodules (Potter et al. 2013). In contrast, shaped tools are mostly absent from the Keystone Dune occupation, and the artifact diversity observed at Swan Point CZ4b is consistent with the production of composite tools only (Lanoë and Holmes 2016).

The faunal assemblages in Broken Mammoth CZ3 and Mead CZ4 are dominated by bison and wapiti but a wider array of animal species were also recovered, particularly in Broken Mammoth CZ3 (Table 5). The faunal composition suggests that the sites supported both short and longdistance forays that targeted different animal resources. It is not known whether bison or wapiti primary or secondary butchering occurred on site, but the faunal assemblages are strikingly different than at a specialized field butchering site (e.g. Potter 2007), or the monospecific assemblage of Keystone Dune (Table 5).

\begin{tabular}{|l|c|c|c|}
\hline Occupation & Lithic Tools & Bone Tools \& Art & Animal Remains \\
\hline Broken Mammoth CZ3 & $\begin{array}{c}\text { bifaces } \\
\text { points } \\
\text { scrapers }\end{array}$ & $\begin{array}{c}\text { ivory points } \\
\text { decorated bone rod } \\
\text { bone needle }\end{array}$ & $\begin{array}{c}\text { bison, wapiti, waterfowl, hare, fish, gamefowl, } \\
\text { fox, sheep, marmot, caribou, wolf }\end{array}$ \\
\hline Mead CZ4 & $\begin{array}{c}\text { bifaces } \\
\text { burins } \\
\text { scrapers }\end{array}$ & $\begin{array}{c}\text { antler billet } \\
\text { worked ivory? }\end{array}$ & bison, waterfowl, wapiti \\
\hline Swan Point CZ4b & $\begin{array}{c}\text { ivory rod } \\
\text { ivory blanks } \\
\text { burins } \\
\text { birdler blanks }\end{array}$ & $\begin{array}{c}\text { mammoth, waterfowl, horse, gamefowl, hare, } \\
\text { caribou }\end{array}$ \\
\hline Keystone Dune & scraper & - & wapiti \\
\hline
\end{tabular}

Table 5. Diversity of archaeological materials at several Late Glacial occupations in the Shaw Creek Flats (from Yesner 1994, 1996, 2001, Holmes 1996, 2011, Yesner et al. 2000, Potter et al. 2013, Goebel and Potter 2016, Lanoë and Holmes 2016, Reuther et al. 2016). Animal remains are listed in order of decreasing NISP frequency.

Some degree of spatial structure can be recognized in the Late Glacial occupations in the Shaw Creek Flats. Associations of hearths with drop zones related to lithic reduction or fauna consumption are typical of ethnographic and archaeological contexts (Binford 1983; e.g. LeroiGourhan and Brézillon 1972) and are found in Mead CZ4 (Potter et al. 2013), Broken Mammoth 
CZ3 (Krasinski and Yesner 2008), Swan Point CZ4b (Lanoë and Holmes 2016), and at Keystone Dune (see below). Constraints on the distribution of artifacts that are characteristic of constructed structures (Leesch and Bullinger 2012; Stapert 2003) are also found at all four occupations.

The occupations differ at other levels of spatial organization. At Mead CZ4, archaeological materials show a bimodal distribution around hearth F2011-6. High density areas are located within 1 meter and more than 3 meters from the hearth, while the area in between is empty of materials (Potter et al. 2013, fig. 5.2). In contrast, an area up to $3 \mathrm{~m}$ around the south hearth at Swan Point CZ4b is littered with waste (Lanoë and Holmes 2016). The spatial distribution of materials at Mead CZ4 is typical of a habitation structure in which the living area was regularly cleaned and relocated to dumps near the door. This pattern suggests that people stayed at Mead long enough to be bothered by the accumulation of waste indoors.

\section{Hunting Bison and Wapiti}

Bison and wapiti dominate the Late Glacial archeofaunal record in the Shaw Creek Flats (Figure 2) even though other large herbivores, such as caribou (Rangifer tarandus), Dall sheep (Ovis dalli), and moose, were present in the landscape (Yesner 2001). The exception to the dominance of bison and wapiti is Swan Point CZ4b, where food consumption was minimal and where the vast majority of animal remains correspond to animal tissues used as raw material (Lanoë and Holmes 2016). Bison and wapiti probably formed a staple of the economy until the Early Holocene throughout subarctic eastern Beringia (Potter 2008, 2011), and emphasis on these two ungulate species must have played a large part in determining the economic and mobility strategies of Late Glacial people. 


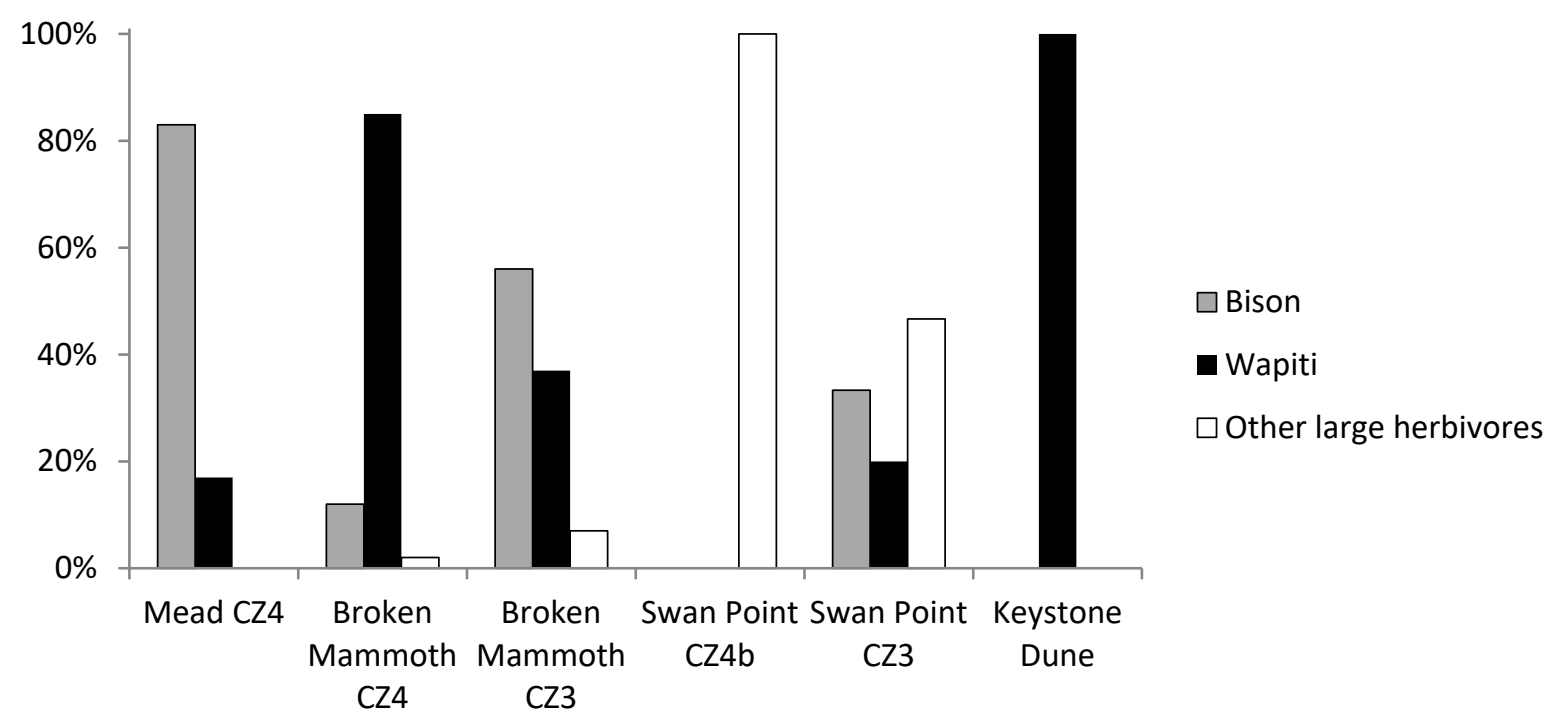

Figure 2. Distribution of large herbivore species (proportion of NISP) at Late Glacial occupations in the Shaw Creek Flats (from Yesner 2001, Potter et al. 2013, Lanoë and Holmes 2016, Reuther et al. 2016, Lanoë et al. 2017).

Bison and wapiti prefer grasslands or early successional habitat dominated by graminoids, forbs, and a limited amount of leafy vegetation (Guthrie 1983, 1990; McCabe 2002; Stephenson et al. 2001). In eastern Beringia, prior to 14,000 cal B.P., they occupied a niche intermediate to specialized grazers such as horse or mammoth, and specialized browsers such as moose, but they would have used grasslands more after the extinction of mammoth and horse (Lanoë et al. 2017).

Grassland patches in the Late Glacial were more extensive than today. Locally favorable conditions included xeric areas with higher drainage, insulation, and aeolian activity (Guthrie 1983, 2001), as well as areas with cyclic disturbance from high-energy alluvial and aeolian sedimentation which would have maintained soils and vegetation in an early successional stage (Reuther et al. 2016; Stephenson et al. 2001). Early successional habitat on gravel bars and alluvial terraces is used today by introduced plains bison (Bison bison) near the confluence of the Tanana and Delta rivers $25 \mathrm{~km}$ south of the Shaw Creek Flats (Glassburn 2015). Because of seasonal changes in forage quality and availability, bison and wapiti probably moved between these different types of habitats throughout the year, generally favoring uplands in the summer and lowlands in the winter (Glassburn 2015; Guthrie 1983; Rasic 2011).

Figure 1 shows a model of distribution of favorable grassland habitat during the Late Glacial in the Shaw Creek Flats, assuming that steep and south-oriented slopes of the Uplands provided dry conditions and that the depositing sand sheet provided enough disturbance to maintain soil and vegetation in an early successional stage. Following this model, favorable bison and wapiti habitat would have centered on the southern slopes of the Yukon-Tanana Uplands on the northern edge of the Flats, where the Keystone Dune site is located. These patches were probably 
favored in the summer, while suitable winter habitat may have been located along the Tanana River. Most of the lowlands, though, are likely to have concentrated gallery forests, shrub birch, and nascent wetlands, creating a habitat more favorable for the specialized browser and wetlandadapted moose.

\section{The Keystone Dune Site: A Wapiti Hunting Camp}

The Keystone Dune site (XBD-363) is situated in the Rosa-Keystone dunefield, at the northeastern horn of a parabolic dune, and overlooks Keystone Creek and its valley. The dune is composed of horizontal beds of coarse to fine sands, in which a cut up to $15 \mathrm{~m}$ deep was created by a local mining road (Reuther et al. 2016).

The archaeological occupation did not yield diagnostic artifacts but may be assigned to Phase II of the Beringian tradition (Holmes 2011) from its age, which at 13,400-13,220 cal B.P. (concordant dates on bone collagen and charcoal from hearth materials) is similar to other sites in the Shaw Creek Flats (Table 2). All in-situ archaeological materials were found on the same surface, associated with a charred Ab horizon that shows little to no evidence of postdepositional disturbance; no other occupations were recorded at the dune despite extensive testing of the erosional surface (Reuther et al. 2016). High-energy sediment deposition (Table 3) favored the spatial preservation of the archaeological occupation, but a portion of it was removed by the erosion of the dune along the roadcut. 


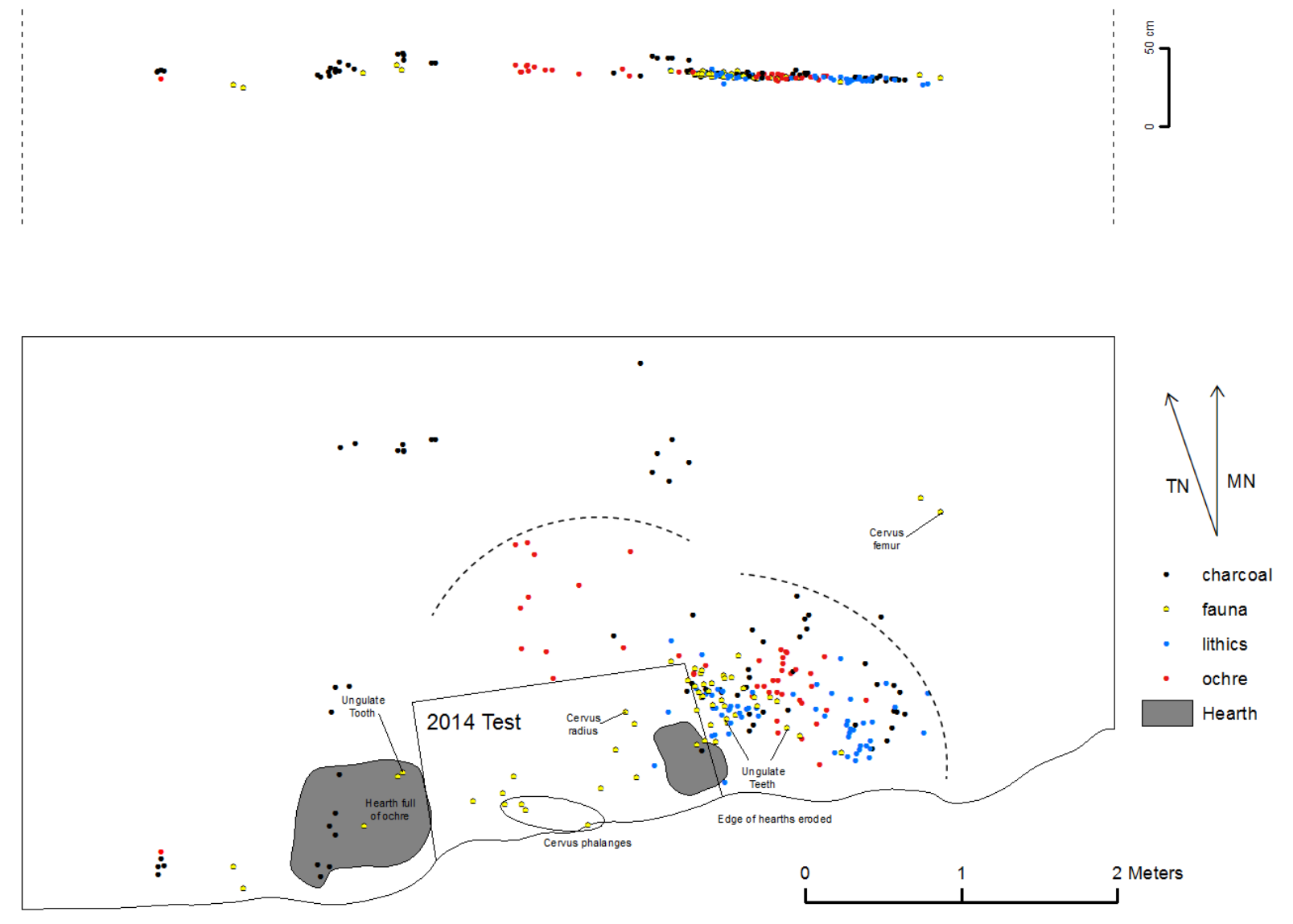

Figure 3. Profile and map of the Keystone Dune site. Locations of artifacts in the 2014 test are estimated from photographs. The dashed lines indicate the possible location of walls constraining artifact dispersal away from the hearth.

Archaeological materials are distributed in relation to two hearths (Figure 3). Lithic artifacts recovered in situ consist almost exclusively of small reduction by-products $(95.0 \%$ smaller than $10 \mathrm{~mm}$; Table 6). They are organized in two clusters centered 0.41 and $1.07 \mathrm{~m}$ east from the eastern hearth and represent a drop zone around the hearth characteristic of hunter-gatherer camps (Binford 1983; e.g. Leroi-Gourhan and Brézillon 1972). Lithic specimens were also recovered at the bottom of the dune during survey (Table 6), corresponding to artifacts that were most likely located south of the hearths and later eroded away with this portion of the dune. While suffering from an obvious size taphonomic bias, they still are larger $\left(\chi^{2}=80.9 ; d f=4 ; p<\right.$ 0.01 ) and may relate to artifacts removed from the main activity area by cleaning, tossing, or recycling (see Binford 1983; Stiger 2006; Waguespack and Surovell 2014).

\begin{tabular}{|l|c|c|c|}
\hline & $\begin{array}{c}\text { Materials } \\
\text { in situ }\end{array}$ & $\begin{array}{c}\text { Downslope from } \\
\text { excavation block }\end{array}$ & $\begin{array}{c}\text { Unprovenienced } \\
\text { surface finds }\end{array}$ \\
\hline Size range $\mathbf{( m m )}$ & \multicolumn{2}{|l}{} \\
\hline
\end{tabular}




\begin{tabular}{|c|c|c|c|}
\hline $0-5$ & 48 & 2 & \\
\hline $5-10$ & 104 & 11 & 70 \\
\hline $10-15$ & 16 & 15 & 65 \\
\hline $15-20$ & 5 & 11 & 25 \\
\hline$>20$ & 3 & 12 & 43 \\
\hline \multicolumn{4}{|l|}{ Typology } \\
\hline Cores & 0 & 1 & \\
\hline $\begin{array}{l}\text { Unretouched flake } \\
\text { [biface thinning flake] }\end{array}$ & $\begin{array}{l}175 \\
{[2]}\end{array}$ & $\begin{array}{l}50 \\
{[4]}\end{array}$ & $\begin{array}{l}198 \\
{[6]}\end{array}$ \\
\hline Unifacial tools & 1 & & 1 \\
\hline Bifacial tools & & & 4 \\
\hline \multicolumn{4}{|l|}{ Raw material } \\
\hline Basalt & 157 & 32 & 53 \\
\hline Rhyolite & 1 & 7 & 41 \\
\hline Chert & 18 & 12 & 109 \\
\hline
\end{tabular}

Table 6. Lithic materials recovered at the Keystone Dune Site. Specimens recorded near the hearth are significantly smaller than surface finds below the excavation block $\left(\chi^{2}=80.9 ; d f=4\right.$; $p<0.01)$ or in other areas of the dune $\left(\chi^{2}=131.1 ; d f=4 ; p<0.01\right)$.

The faunal materials located immediately east of the eastern hearth (Figure 3) consist of small unidentifiable bone fragments with generally poor preservation causing them to crumble upon contact (Table 7, Figure 4). Similar to the situation for the lithic débitage, this concentration of small bone fragments can be interpreted as a drop zone. People broke bones, likely during extraction of medullary marrow from long bones. Larger bone specimens are scattered in other areas of the site and generally are better preserved; those items were removed deliberately from the activity area. Overall, the faunal specimens are consistent with the consumption of tissues from two limbs of a single wapiti. Most of the portions of the wapiti carcass did not reach the site or were taken away subsequently.

\begin{tabular}{|c|c|c|}
\hline & $\begin{array}{c}\text { East of the } \\
\text { hearth }\end{array}$ & $\begin{array}{l}\text { Away from } \\
\text { the hearth }\end{array}$ \\
\hline $\begin{array}{l}\text { Average size }(\mathrm{mm}) \pm \sigma \\
\text { [number measured] }\end{array}$ & $\begin{array}{c}13.6 \pm 17.3 \\
{[14]}\end{array}$ & $\begin{array}{c}65.2 \pm 52.1 \\
{[5]}\end{array}$ \\
\hline $\begin{array}{l}\text { Unidentified NSP } \\
\text { not recovered } \\
\text { mostly cancellous bone } \\
\text { mostly compact bone }\end{array}$ & $\begin{array}{c}6 \\
18 \\
42\end{array}$ & $\begin{array}{l}5 \\
3\end{array}$ \\
\hline $\begin{array}{l}\text { Ungulate NISP } \\
\text { tooth fragment } \\
\text { long bone } \\
\text { rib }\end{array}$ & $\begin{array}{c}39 \\
1\end{array}$ & 2 \\
\hline
\end{tabular}




\begin{tabular}{|c|c|c|}
\hline $\begin{array}{l}\text { Cervid NISP } \\
\text { femur } \\
\text { radius }\end{array}$ & & $\begin{array}{l}3 \\
1\end{array}$ \\
\hline Wapiti NISP & & \\
\hline proximal phalanx & & 2 \\
\hline mesial phalanx & & 2 \\
\hline distal phalanx & & 1 \\
\hline Total & 106 & 20 \\
\hline
\end{tabular}

Table 7. Faunal materials recovered at the Keystone Dune Site. Levels of taxonomic identification are significantly higher $\left(\chi^{2}=51.7 ; d f=3 ; p<0.01\right)$ and specimens significantly larger $(\mathrm{t}=2.2 ; d f=4.1 ; p=0.09)$ in areas away from the eastern hearth.
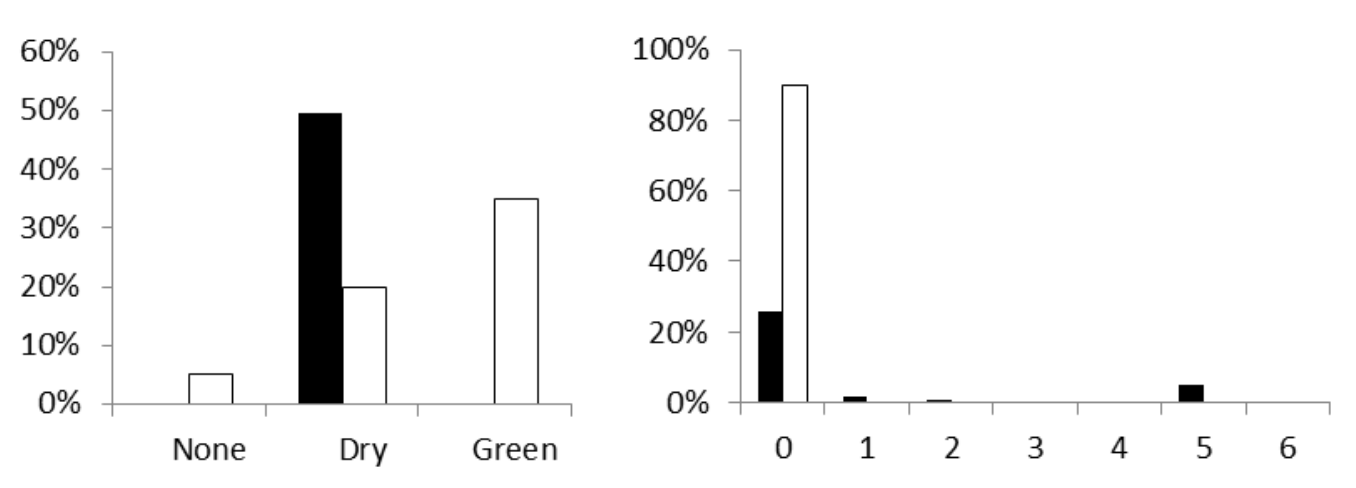

Figure 4. Taphonomic characteristics of the Keystone Dune faunal assemblage (proportion of NISP). Left: breakage type. Right: burning stages following Stiner et al. (1995), with 0: unburned; 1-3: partly to wholly carbonized; and 4-6: partly to wholly calcined. Materials in or near the eastern hearth are in black, materials in other zones are in white. Differences between the subsamples are significant for burning $\left(\chi^{2}=30.2 ; d f=4 ; p<0.01\right)$ and breaking $\left(\chi^{2}=45.6 ; d f\right.$ $=3 ; p<0.01$ ).

Clusters of materials are well defined: the mean distance between specimens in each cluster ranges between $3.6 \mathrm{~cm}$ (western lithic drop zone), $5.8 \mathrm{~cm}$ (fauna drop zone), and $6.1 \mathrm{~cm}$ (eastern lithic drop zone). The rest of the area excavated is otherwise void of materials (Figure 3, Table 6, Table 7). This sharp spatial definition suggests limited horizontal disturbance from trampling, cleaning or reuse of space for multiple activities. Strict delineation of the dense material zone to the east of the eastern hearth also suggests a spatial constraint on the circulation of artifacts, an effect typically created by a physical barrier (Stapert 2003; Surovell and Waguespack 2007). Likewise, charcoal and ochre specks are limited to this same area and indicate scattering and/or trampling within a confined space. Assuming this area constraining artifact spatial distribution relates to a constructed structure, the eastern hearth would have been located at its western entrance. Drop zones related to maintenance and consumption activities would have been located 
between the hearth and a wall. A waste zone resulting from rough cleaning would have been located by the opening, as is typical of the hunter-gatherer ethnographic and archaeological records (Binford 1983; Bodu et al. 2006; Surovell and O’Brien 2016; Waguespack and Surovell 2014).

While the excavation window is not extensive and the occupation may extend over a larger area, the Keystone Dune site still meets the expectations of a short-term task-specific site (Table 1) by its location on the landscape as well as by its composition and spatial layout. The absence of complex tools or reduction processes suggests that technological activities were limited to repair or maintenance of tools brought into the site. The character of the faunal assemblage and the lack of explicit spatial maintenance or elaborate structures suggest that only a few people stayed at the site for a limited amount of time. The site was probably used specifically as a hunting camp; that is, a base used by hunters for rest and preparation before and after hunting expeditions in the nearby wapiti hunting grounds.

\section{Swan Point CZ4b: A Short-Term Specialized Occupation}

Swan Point CZ4b is located on top of a knoll overlooking the Shaw Creek Flats and the southern slopes of the Yukon-Tanana Uplands (Dilley 1998; Holmes 2011; Lanoë and Holmes 2016). The location of the site as well as the material composition and spatial layout of the CZ4b occupation indicate that it was used specifically for the acquisition and transformation of organic raw materials.

Combined information from lithic and organic materials indicates a focus on the production or maintenance of composite tools. Microblades and organic blanks were produced and probably assembled at the site in well-delineated manufacturing areas, including several associations of hearths and drop zones (Lanoë and Holmes 2016; Figure 5). The artifacts recovered, although numerous (Table 4), are not very diverse (Table 5) and all relate to the different steps of the complex chaîne opératoire to produce composite microblade organic tools. 


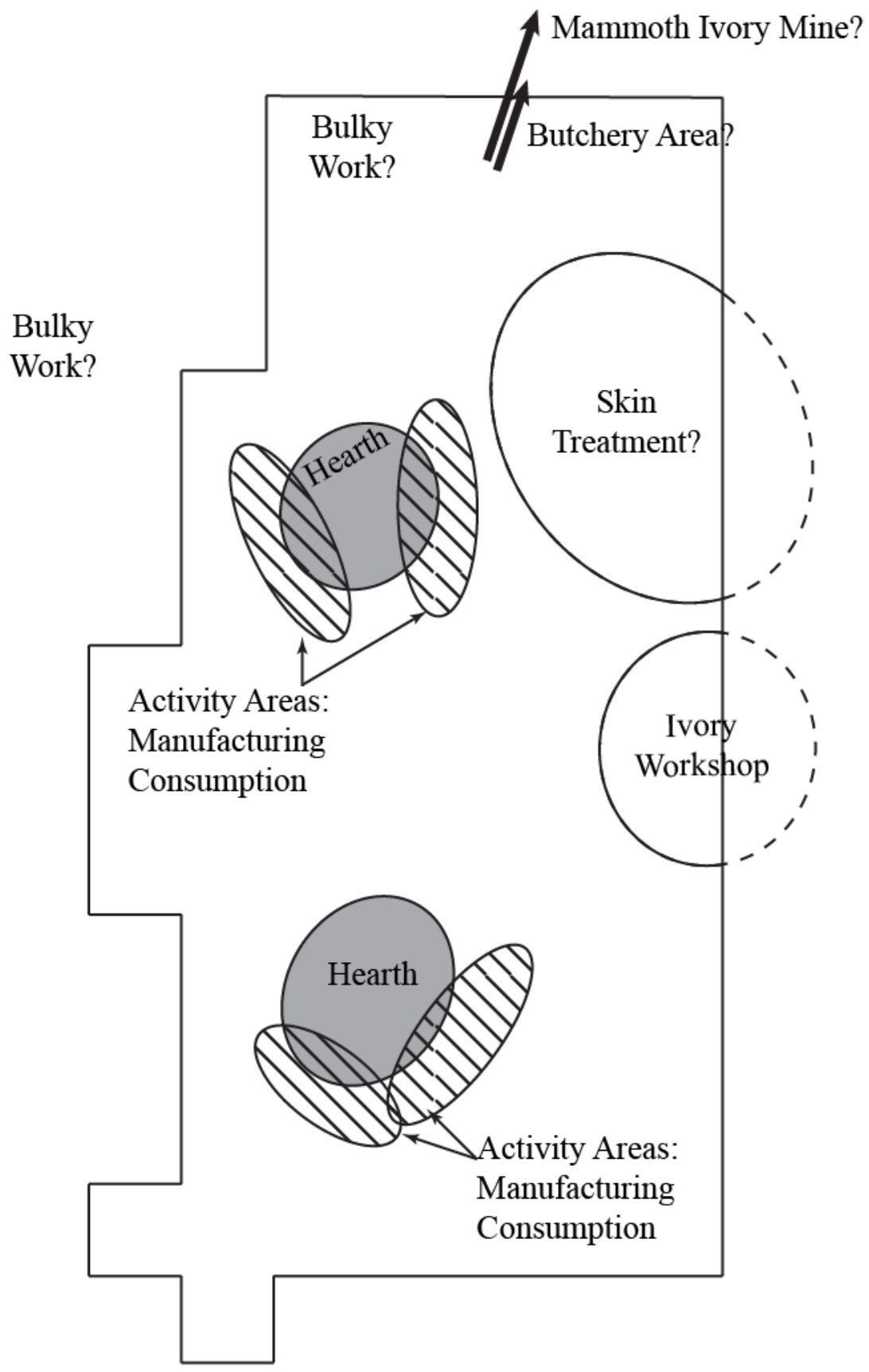

Figure 5. Interpretation of the use of space at Swan Point CZ4b (reproduced from Lanoë and Holmes [2016]).

Despite a high density of archaeological materials (Table 4), Swan Point CZ4b was likely used by only a few people and for a short time. The spatial distribution of the materials at Swan Point CZ4b suggests the existence of a constructed structure centered on one of the hearths. Different types of materials form delineated clusters suggesting an absence of cleaning or extensive 
trampling during the occupation. Such characteristics do not suggest that the site was used over a long time (Supplemental Text 1). Moreover, there is no evidence of primary butchery and largescale consumption of ungulates. Faunal remains, however diverse (Table 5), relate closely to the technological activities (Lanoë and Holmes 2016). The other faunal specimens, which can reasonably be interpreted as resulting from a food consumption activity, represent less than $50,000 \mathrm{Kcal}$ worth, even while assuming poor skeletal preservation. This limited amount of food would have, at best, sustained a small party for less than two weeks (Supplemental Text 2).

Swan Point was an ideal location for a workshop given this proximity to raw material sources. It is located in the middle of wetlands that provided favorable habitat for waterfowl. The site was also probably located in the vicinity of natural accumulations of mammoth ivory. People brought numerous pieces of fossil or subfossil ivory to the site, some of them so large that it would have been impractical to transport them over long distances (Lanoë and Holmes 2016), suggesting that they took advantage of a nearby ivory "mine," as has been argued for other Upper Paleolithic sites rich in mammoth ivory specimens (Pitulko et al. 2015; Steguweit 2015).

\section{Discussion}

The Late Glacial archaeological record of the Shaw Creek Flats is exceptionally dense and wellpreserved in comparison to most regions of northeastern Eurasia and the Americas. Archaeological occupations are well-preserved both in terms of their archaeological assemblages and their spatial layouts, thanks to the high rates of fine sediment deposition during the Late Glacial. Hunter-gatherer task-specific sites characterized by low-densities of archaeological materials typically become blurred into palimpsests because the location was re-used for different purposes and/or by different groups (Hoffecker 2011; Rasic 2011). In contrast, the sites in the Shaw Creek Flats have high chronological resolution that provides synchronic "snapshots" in time.

Late Glacial people in the Shaw Creek Flats exploited resources in an intricate, logistical fashion. Sites used for residential, longer-term purposes were strategically located to access everyday resources while also accommodating residential mobility. Residential sites centralized the acquisition of resources within the larger landscape. Some of these resources, including food items and raw materials, were acquired and processed at specialized sites before being transported to residential sites. This heterogeneity in site types explains much of the lithic variability (i.e. bifaces vs. microblades) observed for the period (Potter 2011; Rasic 2011).

Short-term, task-specific sites attest to the importance of logistical mobility in the economic system in the Shaw Creek Flats. Archaeological research has tended to focus on landforms overlooking the Tanana River where residential sites are likely to be found, and these typically show larger quantities of archaeological materials. Task-specific sites do exist, but are likely to be found in other landforms, and be more difficult to identify than residential sites. We expect 
that future surveys deeper in the Flats will increase the number of known task-specific occupations. Documenting these occupations will in turn considerably improve our knowledge of economic and mobility strategies of Late Glacial people in central Alaska.

Potential resources for Late Glacial people in the Shaw Creek Flats included those from wetlands and forested areas that were dominated by moose; grasslands dominated by bison and wapiti; and uplands dominated by caribou and sheep. Among this range of potential resources, people chose to focus on those from grasslands. Grassland resources, particularly bison and wapiti, would have been more attractive to people (and any other large predator), or higher-ranked (Lanoë et al. 2017) because these resources tend to be heterogeneously distributed - more or less gregarious herds that may have moved along known geographic features at specific times of the year (e.g. Glassburn 2015). In contrast, resources from forested areas tend to be more homogeneously available, with more solitary animals distributed in a more random pattern. People probably adopted a logistical mobility primarily to reduce the search and transport costs associated with the acquisition of resources that were distributed heterogeneously. In contrast, had people followed a purely-residential mobility strategy, they may have favored resources from wetlands or forested areas., for instance moving and exploiting moose populations along a geographic gradient within the lowlands.

Late Glacial Paleoindian/Paleoarctic people in subarctic eastern Beringia do not seem to have behaved as free-wandering groups exhausting megafauna along long-distance travels as once modeled by Kelly and Todd (1988). Instead, they seem to have had an excellent knowledge of the resource geography of a patchy landscape (Kelly 2003), probably occupied well-defined territories (Rasic 2011), and perceived the local landscape and its components at a fine temporal and spatial scale. In that aspect they were similar to other Paleoindian groups documented in the Great Basin and Pacific Northwest (Chatters et al. 2012; Jones et al. 2003; Jones and Beck 2012). In other aspects related to the importance of residential versus logistical mobility, people of the Shaw Creek Flats seem to add to the diversity of economic strategies observed among North American hunter-gatherers in the Late Pleistocene and Early Holocene, suggesting that Paleoindian economic and mobility strategies depended, to a large extent, on local factors.

Major changes in economic and mobility strategies in subarctic eastern Beringia must have paralleled local environmental and ecological changes. The extinction of several megafauna species and populations during the Bølling-Allerød was a major change in the structure of mammalian communities (Lanoë et al. 2017), but it was not the only one in the recent history of eastern Beringia. People were probably as much or even more affected by the establishment of the modern biomes in the Early to Middle Holocene (Kaufman et al. 2016). Resources from grasslands may have dwindled to the point that they were not economically viable anymore for hunter-gatherer groups, and people may have been forced to reorient their economic and mobility strategies to target resources from the boreal forest and tundra habitats (Esdale 2008; Potter 2008, 2016). 


\section{Supplemental Materials}

Supplemental Text 1. Evidence for a constructed structure at Swan Point CZ4b.

Supplemental Text 2. Estimation of the length of stay at Swan Point CZ4b.

\section{Data Availability Statement}

Artifacts and associated spatial data from the Keystone Dune and Swan Point sites are curated at the University of Alaska Museum of the North in Fairbanks. 


\section{References}

Anderson, P. M., \& Brubaker, L. B. (1994). Vegetation History of Northcentral Alaska: A Mapped Summary of Late-Quaternary Pollen Data. Quaternary Science Reviews, 13, 71-92.

Anderson, P. M., Edwards, M. E., \& Brubaker, L. B. (2004). Results and Paleoclimate Implications of 35 Years of Paleoecological Research in Alaska. Developments in Quaternary Science, 1, 427-440.

Bamforth, D. B. (2003). Rethinking the Role of Bifacial Technology in Paleoindian Adaptations on the Great Plains. In M. Soressi \& H. Dibble (Eds.), Multiple Approaches to the Study of Bifacial Technology (pp. 209-228). Philadelphia: University of Pennsylvania Museum.

Barber, V. A., \& Finney, B. P. (2000). Late Quaternary Paleoclimatic Reconstructions for Interior Alaska Based on Paleolake-Level Data and Hydrologic Models. Journal of Paleolimnology, 24, 29-41.

Bigelow, N. H. (1997). Late Quaternary Vegetation and Lake Level Changes in Central Alaska. PhD Dissertation, University of Alaska Fairbanks.

Bigelow, N. H., \& Powers, W. R. (2001). Climate, Vegetation, and Archaeology 14,000-9,000 Cal Yr B.P. in Central Alaska. Arctic Anthropology, 38(2), 171-195.

Binford, L. R. (1978). Nunamiut Ethnoarchaeology. New York: Academic Press.

Binford, L. R. (1980). Willow Smoke and Dogs' Tails: Hunter-Gatherer Settlement Systems and Archaeological Site Formation. American Antiquity, 45, 4-20.

Binford, L. R. (1982). The Archaeology of Place. Journal of Anthropological Archaeology, 1(1), 5-31.

Binford, L. R. (1983). In Pursuit of the Past. New York: Thames and Hudson.

Bird, D. W., \& O’Connell, J. F. (2006). Behavioral Ecology and Archaeology. Journal of Archaeological Research, 14(2), 143-188.

Bodu, P., Julien, M., Valentin, B., \& Debout, G. (Eds.). (2006). Un dernier hiver à Pincevent : les Magdaléniens du niveau IV0. Gallia Préhistoire.

Bronk Ramsey, C. (1994). Analysis of Chronological Information and Radiocarbon Calibration : The Program OxCal. Archaeological Computing Newsletter, 41, 11-16.

Bronk Ramsey, C. (2009). Bayesian Analysis of Radiocarbon Dates. Radiocarbon, 51(1), 337360. 
Chapin III, F. S., Hollingsworth, T., Murray, D. F., Viereck, L. A., \& Walker, M. D. (2006). Floristic Diversity and Vegetation Distribution in the Alaskan Boreal Forest. In F. S. Chapin III, M. W. Oswood, K. Van Cleve, L. A. Viereck, \& D. L. Verbyla (Eds.), Alaska's Changing Boreal Forest (pp. 81-99). New York: Oxford University Press.

Chatters, J. C., Hackenberger, S., Prentiss, A. M., \& Thomas, J.-L. (2012). The Paleoindian indian to Archaic Transition in the Pacific Northwest: In Situ Development or Ethnic Replacement? In C. B. Bousman, B. Vierra, \& G. T. Jones (Eds.), From the Pleistocene to the Holocene (pp. 100-173). College Station: Texas A\&M University Press.

Choy, K., Potter, B. A., McKinney, H. J., Reuther, J. D., Wang, S. W., \& Wooller, M. J. (2016). Chemical profiling of ancient hearths reveals recurrent salmon use in Ice Age Beringia. Proceedings of the National Academy of Sciences, 113(35), 9757-9762.

Clark, A. E. (2016). Time and Space in the Middle Paleolithic: Spatial Structure and Occupation Dynamics of Seven Open-Air Sites. Evolutionary Anthropology, 25(3), 153-163.

Dilley, T. E. (1998). Late Quaternary Loess Stratigraphy, Soils, and Environments of the Shaw Creek Flats Paleoindian Sites, Tanana Valley, Alaska. PhD Dissertation, University of Arizona.

Esdale, J. A. (2008). A Current Synthesis of the Northern Archaic. Arctic Anthropology, 45(2), 3-38.

Glassburn, C. L. (2015). A Reconstruction of Steppe Bison Mobility in the Yukon-Tanana Uplands and Implications for Prehistoric Human Behavior. Master's Thesis, University of Alaska Fairbanks.

Goebel, T., \& Potter, B. A. (2016). First Traces: Late Pleistocene Human Settlement of the Arctic. In T. M. Friesen \& O. K. Mason (Eds.), The Oxford Handbook of the Prehistoric Arctic (pp. 223-252). Oxford University Press.

Gómez Coutouly, Y. A. (2012). Pressure Microblade Industries in Pleistocene-Holocene Interior Alaska: Current Data and Discussions. In P. M. Desrosiers (Ed.), The Emergence of Pressure Blade Making: From Origin to Modern Experimentation. Boston, MA: Springer US.

Graf, K. E., \& Bigelow, N. H. (2011). Human Response to Climate During the Younger Dryas Chronozone in Central Alaska. Quaternary International, 242(2), 434-451.

Grove, M. (2009). Hunter-Gatherer Movement Patterns: Causes and Constraints. Journal of Anthropological Archaeology, 28, 222-233.

Guthrie, R. D. (1983). Paleoecology of the Site and Its Implications for Early Hunters. In W. R. Powers, R. D. Guthrie, \& J. F. Hoffecker (Eds.), Dry Creek: Archaeology and Paleoecology of a Late Pleistocene Alaskan Hunting Camp (pp. 209-287). Report Filed with the National Park Service. 
Guthrie, R. D. (1990). Frozen Fauna of the Mammoth Steppe. University of Chicago Press.

Guthrie, R. D. (2001). Origin and Causes of the Mammoth Steppe: A Story of Cloud Cover, Woolly Mammal Tooth Pits, Buckles, and Inside-Out Beringia. Quaternary Science Reviews, 20, 549-574.

Guthrie, R. D. (2006). New Carbon Dates Link Climatic Change with Human Colonization and Pleistocene Extinctions. Nature, 441, 207-9.

Halffman, C. M., Potter, B. a., McKinney, H. J., Finney, B. P., Rodrigues, A. T., Yang, D. Y., \& Kemp, B. M. (2015). Early Human Use of Anadromous Salmon in North America at 11,500 y ago. Proceedings of the National Academy of Sciences, 112(40), 12344-12348.

Hoffecker, J. F. (2011). Assemblage variability in Beringia: The Mesa factor. In T. Goebel \& I. Buvit (Eds.), From the Yenisei to the Yukon: Interpreting Lithic Assemblage Variability in Late Pleistocene/Early Holocene Beringia (pp. 165-178). College Station: Texas A\&M University Press.

Holmes, C. E. (1996). Broken Mammoth. In F. H. West (Ed.), American Beginnings: The Prehistory and Palaeoecology of Beringia (pp. 312-319). University of Chicago Press.

Holmes, C. E. (2011). The Beringian and Transitional Periods in Alaska: Technology of the East Beringian Tradition as Viewed from Swan Point. In T. Goebel \& I. Buvit (Eds.), From the Yenisei to the Yukon: Interpreting Lithic Assemblage Variability in Late Pleistocene/Early Holocene Beringia (pp. 179-191). College Station, TX: Texas A\&M University Press.

Holmes, C. E. (2014). New Evidence Pertaining to the Early Archaeological Sequence at Swan Point , Central Alaska. Poster Presented at the 41st Annual Meeting of the Alaska Anthropological Association, Fairbanks, AK, March 5-8.

Holmes, C. E., VanderHoek, R., \& Dilley, T. E. (1996). Swan Point. In F. H. West (Ed.), American Beginnings: The Prehistory and Palaeoecology of Beringia (pp. 319-322). University of Chicago Press.

Jochim, M. A. (2006). Regional Perspectives on Early Mesolithic Land Use in Southwestern Germany. Journal of Anthropological Archaeology, 25(2), 204-212.

Jones, G. T., \& Beck, C. (2012). The Emergence of the Desert Archaic in the Great Basin. In C. B. Bousman, B. Vierra, \& G. T. Jones (Eds.), From the Pleistocene to the Holocene (pp. 267317). College Station: Texas A\&M University Press.

Jones, G. T., Beck, C., Jones, E. E., \& Hughes, R. E. (2003). Lithic Source Use and Paleoarchaic Foraging Territories in the Great Basin. American Antiquity, 68(1), 5-38. doi:10.2307/3557031 
Kaufman, D. S., Axford, Y. L., Henderson, A. C. G., McKay, N. P., Oswald, W. W., Saenger, C., et al. (2016). Holocene Climate Changes in Eastern Beringia (NW North America) - A Systematic Review of Multi-Proxy Evidence. Quaternary Science Reviews, 147, 312-339.

Kedrowski, B. L., Crass, B. A., Behm, J. A., Luetke, J. C., Nichols, A. L., Moreck, A. M., \& Holmes, C. E. (2009). Gc/Ms Analysis of Fatty Acids from Ancient Hearth Residues at the Swan Point Archaeological Site. Archaeometry, 51(1), 110-122.

Kelly, R. L. (1983). Hunter-Gatherer Mobility Strategies. Journal of Anthropological Research, 39(3), 277-306.

Kelly, R. L. (2013). The Lifeways of Hunter-Gatherers: The Foraging Spectrum. Cambridge University Press.

Kelly, R. L., \& Todd, L. C. (1988). Coming into the Country: Early Paleoindian Hunting and Mobility. American Antiquity, 53(2), 231-244.

Krasinski, K., \& Yesner, D. R. (2008). Late Pleistocene-Early Holocene Site Structure in Beringia. Alaska Journal of Anthropology, 6, 27-41.

Lanoë, F. B., \& Holmes, C. E. (2016). Animals as Raw Materials in Beringia: Insights from the Site of Swan Point CZ4b, Alaska. American Antiquity, 81(4), 682-696.

Lanoë, F. B., Reuther, J. D., Holmes, C. E., \& Hodgins, G. (2017). The Lion’s Share: Human Paleoecological Integration in Eastern Beringia. Submitted to Quaternary Science Reviews.

Leesch, D., \& Bullinger, J. (2012). Identifying Dwellings in Upper Palaeolithic Open-Air Sites The Magdalenian Site at Monruz and its Contribution to Analysing Palimpsests. In M. Niekus, R. Barton, M. Street, \& T. Terberger (Eds.), A Mind Set on Flint. Studies in Honour of Dick Stapert (pp. 165-181). Groningen University.

Leroi-Gourhan, A., \& Brézillon, M. (1972). Fouilles de Pincevent - Essai d'analyse ethnographique d'un habitat magdalénien (la section 36). Paris: CNRS, VII supplement to Gallia Préhistoire.

McCabe, R. E. (Ed.). (2002). North American Elk: Ecology and Management. Washington, D.C.: Smithsonian Institution Press.

Pitulko, V. V., Pavlova, E. Y., \& Nikolskiy, P. a. (2015). Mammoth Ivory Technologies in the Upper Palaeolithic: A Case Study Based on the Materials from Yana RHS, Northern YanaIndighirka Lowland, Arctic Siberia. World Archaeology, 47, 333-389.

Potter, B. A. (2007). Models of Faunal Processing and Economy in Early Holocene Interior Alaska. Environmental Archaeology, 12(1), 3-23. 
Potter, B. A. (2008). Radiocarbon Chronology of Central Alaska: Technological Continuity and Economic Change. Radiocarbon, 50(2), 181-204.

Potter, B. A. (2011). Late Pleistocene and Early Holocene Assemblage Variability in Central Alaska. In T. Goebel \& I. Buvit (Eds.), From the Yenisei to the Yukon: Interpreting Lithic Assemblage Variability in Late Pleistocene/Early Holocene Beringia (pp. 215-233). College Station, TX: Center for the Study of the First Americans.

Potter, B. A. (2016). Holocene Prehistory of the Northwestern Subarctic. In T. M. Friesen \& O. K. Mason (Eds.), The Oxford Handbook of the Prehistoric Arctic (pp. 537-562). Oxford University Press.

Potter, B. A., Holmes, C. E., \& Yesner, D. R. (2013). Technology and Economy among the Earliest Prehistoric Foragers in Interior Eastern Beringia. In K. E. Graf, C. V Ketron, \& M. R. Waters (Eds.), Paleoamerican Odyssey (pp. 81-103). College Station, TX: Center for the Study of the First Americans.

Rasic, J. T. (2011). Functional Variability in the Late Pleistocene Archaeological Record of Eastern Beringia: A Model of Late Pleistocene Land Use and Technology from Northwest Alaska. In T. Goebel \& I. Buvit (Eds.), From the Yenisei to the Yukon: Interpreting Lithic Assemblage Variability in Late Pleistocene/Early Holocene Beringia (pp. 128-164). College Station: Texas A\&M University Press.

Reger, R. D., Stevens, D. S. P., \& Solie, D. N. (2008). Surficial Geology of the Alaska Highway Corridor, Delta Junction to Dot Lake, Alaska. Alaska Division of Geologic and Geophysical Surveys.

Reimer, P. J., Bard, E., Bayliss, A., Beck, J., Blackwell, P. G., Bronk Ramsey, C., et al. (2013). IntCal13 and Marine13 Radiocarbon Age Calibration Curves 0-50,000 Years cal BP. Radiocarbon, 55(4), 1869-1887.

Reuther, J. D. (2013). Late Glacial and Early Holocene Geoarchaeology and Terrestrial Paleoecology in the Lowlands of the Middle Tanana Valley, Subarctic Alaska. PhD Dissertation, University of Arizona.

Reuther, J. D., Potter, B. A., Holmes, C. E., Feathers, J. K., Lanoë, F. B., \& Kielhofer, J. (2016). The Rosa-Keystone Dunes Field: The Geoarchaeology and Paleoecology of a Late Quaternary Stabilized Dune Field in Eastern Beringia. The Holocene, 26(12), 1939-1953.

Reuther, J. D., Slobodina, N. S., Rasic, J. T., Cook, J. P., \& Speakman, R. J. (2011). Gaining Momentum: Late Pleistocene and Early Holocene Archaeological Obsidian Source Studies in Interior and Northeastern Beringia. In T. Goebel \& I. Buvit (Eds.), From the Yenisei to the Yukon: Interpreting Lithic Assemblage Variability in Late Pleistocene/Early Holocene Beringia (pp. 270-286). College Station: Texas A\&M University Press. 
Stapert, D. (2003). Towards Dynamic Models of Stone Age Settlements. In S. A. Vasil'ev, O. Soffer, \& J. K. Kozlowski (Eds.), Perceived Landscapes and Built Environments: The Cultural Geography of Late Palaeolithic Eurasia (pp. 5-16). Oxford: BAR International Series 1122, Archaeopress.

Steguweit, L. (2015). Rotten Ivory as Raw Material Source in European Upper Palaeolithic. Quaternary International, 361, 313-318.

Stein, J. K., Deo, J. N., \& Phillips, L. S. (2003). Big Sites—Short Time: Accumulation Rates in Archaeological Sites. Journal of Archaeological Science, 30(3), 297-316.

Stephenson, R. O., Gerlach, S. C., Guthrie, R. D., Harington, C. R., Mills, R. O., \& Hare, G. (2001). Wood Bison in Late Holocene Alaska and Adjacent Canada: Paleontological, Archaeological and Historical Records. In S. C. Gerlach \& M. S. Murray (Eds.), People and Wildlife in Northern North America (pp. 125-133). Oxford: Archaeopress: BAR International Series.

Stiger, M. (2006). A Folsom Structure in the Colorado Mountains. American Antiquity, 71(2), 321-351.

Stiner, M. C., Kuhn, S. L., Weiner, S., \& Bar-Yosef, O. (1995). Differential Burning, Recrystallization, and Fragmentation of Archaeological Bone. Journal of Archaeological Science, 22(2), 223-237.

Surovell, T. A. (2009). Toward a Behavioral Ecology of Lithic Technology: Cases from Paleoindian Archaeology. Tucson: University of Arizona Press.

Surovell, T. A., \& O’Brien, M. (2016). Mobility at the Scale of Meters. Evolutionary Anthropology, 25(3), 142-152. doi:10.1002/evan.21487

Surovell, T. A., \& Waguespack, N. M. (2007). Folsom Hearth-Centered Use of Space at Barger Gulch, Locality B. In R. H. Brunswig \& B. L. Pitblado (Eds.), Emerging Frontiers in Colorado Paleoindian Archaeology (pp. 219-259). Boulder: University of Colorado Press.

Surovell, T. A., \& Waguespack, N. M. (2008). How Many Elephant Kills Are 14? Clovis Mammoth and Mastodon Kills in Context. Quaternary International, 191(1), 82-97.

Théry-Parisot, I., \& Costamagno, S. (2005). Propriétés combustibles des ossements : données expérimentales et réflexions archéologiques sur leur emploi dans les sites paléolithiques. Gallia Préhistoire, 47, 235-254.

Venkataraman, V. V, Kraft, T., Dominy, N. J., \& Endicott, K. M. (2017). Hunter-gatherer residential mobility and the marginal value of rainforest patches. Proceedings of the National Academy of Sciences, 114(12), 3097-3102. 
Waguespack, N. M., \& Surovell, T. A. (2014). A Simple Method for Identifying Households Using Lithic Assemblages: A Case Study from a Folsom Campsite in Middle Park, Colorado. In D. H. MacDonald, W. J. Andrefsky, \& P.-L. Yu (Eds.), Lithics in the West:Using Lithic Analysis to Solve Archaeological Problems in Western North America (pp. 35-49). Missoula: University of Montana Press.

Weber, F. R., Foster, H. L., Keith, T. E. C., \& Dusel-Bacon, C. (1978). Preliminary Geologic Map of the Big Delta Quadrangle, Alaska.

Wooller, M. J., Kurek, J., Gaglioti, B. V., Cwynar, L. C., Bigelow, N. H., Reuther, J. D., et al. (2012). An 11,200 Year Paleolimnological Perspective for Emerging Archaeological Findings at Quartz Lake, Alaska. Journal of Paleolimnology, 48(1), 83-99.

Wygal, B. T., Krasinski, K. E., Holmes, C. E., \& Crass, B. A. (2016). Holzman : A Newly

Discovered Late Pleistocene Occupation in the Tanana Valley, Alaska. Poster Presented at the 43rd Alaska Anthropological Association Meeting, Sitka, AK, March 2-6.

Yesner, D. R. (1994). Subsistence Diversity and Hunter-Gatherer Strategies in late Pleistocene/ early Holocene Beringia: Evidence from the Broken Mammoth Site, Big Delta, Alaska. Current Research in the Pleistocene, 11, 154-156.

Yesner, D. R. (1996). Human Adaptation at the Pleistocene-Holocene (circa 13,000 to 8,000 BP) Boundary in Eastern Beringia. In L. G. Straus, B. V Eriksen, J. M. Erlandson, \& D. R. Yesner (Eds.), Humans at the End of the Ice Age (pp. 255-276). New York: Plenum Press.

Yesner, D. R. (2001). Human Dispersal into Interior Alaska: Antecedent Conditions, Mode of Colonization, and Adaptations. Quaternary Science Reviews, 20(1-3), 315-327.

Yesner, D. R., Pearson, G. A., \& Stone, S. E. (2000). Additional Organic Artifacts from the Broken Mammoth Site, Big Delta, Alaska. Current Research in the Pleistocene, 17, 87-90. 